\title{
PENAWARAN PRODUK IMITASI JENIS FASHION DAN PROSES PENGAMBILAN KEPUTUSAN KONSUMEN DI PASAR KAGET STADION BIMA CIREBON
}

\author{
Moh. Mabruri Faozi dan Annisa Mufidah \\ Fakultas Syari'ah dan Ekonomi Islam \\ Institut Agama Islam Negeri Syekh Nurjati Cirebon \\ e-mail:mabrurifaozi@gmail.com danamoefidah@yahoo.com
}

\begin{abstract}
The market was surprised by the complex of Bima Stadium Cirebon City is one example of the trade center in the municipality of Cirebon imitate an products and visited consumer in a relatively large number of even though there is only every Sunday morning. The spreading of the visitors of this market and the various merchants are available with complete is expected to give description about the product offer imitate an types of fashion and the decision making process of consumers in the market was surprised by the complex of bima stadium of the Cirebon. The research method used is a descriptive qualitative research the process and interpret the data in the form of the arguments and data is non numbers to make a description image or painting systematically, factual and accurate. The results of the study showed that the concept of business that formed in the market was surprised by the complex of bima stadium Cirebon city is the retail outlet with tents or foodtruck as a place where your merchandise, products imitate an types of fashion which circulate in the market was surprised by the complex of bima stadium Cirebon city were very many and diverse consumer decision making is done through the process of decision making process the purchase of consumers.
\end{abstract}

Keywords: The Market Surprised, Products Iimitate, and Decision Making Consumer.

\begin{abstract}
Abstrak
Pasar kaget komplek Stadion Bima kota Cirebon merupakan salah satu contoh sentra perdagangan produk imitasi di kota Cirebon dan dikunjungi konsumen dalam jumlah yang relatif besar meski hanya ada setiap hari minggu pagi. Meratanya pengunjung pasar ini serta berbagai pedagang tersedia dengan lengkap diharapkan dapat memberikan gambaran tentang penawaran produk imitasi jenis fashion dan proses pengambilan keputusan konsumen di pasar kaget komplek Stadion Bima kota Cirebon. Metode penelitian yang digunakan adalah deskriptif kualitatif yaitu mengolah dan menginterpretasikan data berupa argumen serta data yang bersifat non angka untuk membuat deskripsi, gambaran atau lukisan secara sistematis, faktual dan akurat. Hasil penelitian menunjukkan bahwa Konsep bisnis yang terbentuk di pasar kaget komplek Stadion Bima kota Cirebon adalah eceran dengan tendatenda atau foodtruck sebagai tempat dagangannya, produk imitasi jenis fashion yang beredar di pasar kaget komplek Stadion Bima kota Cirebon sangat beragam, pengambilan keputusan konsumen dilakukan melalui proses-proses pengambilan keputusan pembelian konsumen.
\end{abstract}

Kata Kunci: Pasar Kaget, Produk Imitasi, dan Pengambilan Keputusan Konsumen. 


\section{PENDAHULUAN}

Salah satu fenomena yang cukup menarik perhatian penulis yaitu fenomena peredaran produk-produk imitasi (barang tiruan) sebagai sebuah alternatif baru dalam pilihan konsumsi konsumen Indonesia. Jika mau jujur, berapa persen dari seluruh produk yang kita miliki yang benar-benar orisinal? sisanya, bisa merupakan imitasi atau meniru sendiri.

Bahasan ini semakin menarik karena produk imitasi yang dahulunya dianggap hanya mengunggulkan harga yang murah dengan mengabaikan kualitas dari produk yang ditawarkan, ternyata saat ini tidak seluruhnya benar. Terdapat sebuah anggapan bahwa tidak semua barang imitasi kualitasnya rendah, pada kenyataannya banyak barang imitasi sudah mulai menyamai kualitas dari barang yang diimitasinya. Bahkan ada beberapa produsen produk imitasi yang berani menyatakan bahwa produk yang ditawarkannya tidak kalah dengan produk aslinya.

Sebagian produsen produk asli mematok harga yang mahal dikarenakan mereka harus menutup berbagai biaya seperti biaya promosi, di mana sebagian besar perusahaan dunia menganggarkan sepertiga dari anggaran tahunannya untuk biaya ini, biaya penelitian dan pengembangan produk, biaya penyaluran $\&$ distribusi serta pajak yang persentasenya tidak sedikit. ${ }^{1}$

Pasar kaget komplek Stadion Bima kota Cirebon merupakan salah satu contoh sentra perdagangan produk imitasi di Kota Cirebon. Pasar Kaget Komplek Stadion Bima Kota Cirebon merupakan salah satu pasar yang dikunjungi konsumen dalam jumlah yang relative besar walaupun pasar ini hanya ada setiap hari minggu pagi. Pengunjung Pasar Kaget Komplek Stadion Bima Kota Cirebon tiap pekannya diperkirakan mencapai 1000 orang yang

\footnotetext{
${ }^{1}$ Marc Gobe, Emotional Branding: Paradigma Baru untuk Menghubungkan Merek dengan Pelanggan (Jakarta: Esensi, 2005), 24.
}

berasal dari seluruh pelosok Kota Cirebon bahkan yang berasal dari Kabupaten Cirebon. Untuk memahami proses pengambilan keputusan pembelian konsumnen, maka penulis akan membahasnya melalui sudut pandang atribut-atribut program pemasaran sebuah produk (marketing mix).

Produk fashion yang dimaksud penulis disini adalah segala sesuatu yang dapat menunjang bagusnya penampilan seseorang seperti baju, celana, rok, jaket, dasi, topi, tas, sepatu \& kaos kaki, jam tangan, dan aksesoris tubuh lainnya. Konsumen, sebagai individu, perilakunya turut dibentuk oleh faktor psikologis yang terdiri dari motivasi, persepsi, pengetahuan, keyakinan dan pendirian. $^{2}$

Berdasarkan data pra-penelitian yang penulis dapatkan dari Website Harian Radar Cirebon edisi Senin 11 April 2016 yang mengungkapkan bahwa " $80 \%$ pedagang yang berjualan di pasar kaget komplek Stadion Bima menjual pakaian selebihnya tersebar di jenis kuliner dan pernak-pernik lainnya. ${ }^{3}$ Selain itu, pakaian (fashion) merupakan salah satu kebutuhan pokok manusia, sehingga diharapkan penulis tidak terlalu sulit untuk mendapatkan data mengenai hal-hal yang berkaitan dengan kebutuhan data dalam penelitian yang akan dilakukan. Dari uraian diatas, penulis dapat merumuskan masalah-masalah, sebagai berikut 1) Bagaimana konsep bisnis pada pasar kaget komplek Stadion Bima kota Cirebon? 2) Bagaimana penawaran produk imitasi jenis fashion di pasar kaget komplek Stadion Bima kota Cirebon? 3) Bagaimana pengambilan keputusan konsumen di pasar kaget komplek Stadion Bima kota Cirebon?

\footnotetext{
${ }^{2}$ Philip Kotler, Manajemen Pemasaran: Analisis, Perencanaan, Implementasi, dan Pengendalian, Edisi Keenam (Jakarta: Erlangga, 1988), 245.

${ }^{3}$ www.radarcirebon.com. Diakses pada tanggal tanggal 30 Januari 2017.
} 


\section{LITERATURE REVIEW}

Untuk menunjukan fokus dalam penelitian ini, maka peneliti perlu menelaah tentang penelitian yang telah ada. Peneliti juga menggunakan penelitian terdahulu sebagai referensi tambahan selain buku, artikel, dan surat kabar, seperti pertama, penelitian Rina Oktaviana dalam "Hubungan Antara Sikap Konsumen Dengan Keputusan Membeli Produk Perhiasan Imitasi Xuping Pada Konsumen Wanita di Pasar 16 Ilir Palembang". Penelitian ini bertujuan untuk mengetahui apakah ada hubungan antara sikap konsumen dengan keputusan membeli produk perhiasan imitasi Xuping pada konsumen wanita di pasar 16 Ilir Palembang. Subjek penelitian yang digunakan sebanyak 100 orang konsumen wanita di pasar 16 ilit Palembang dengan menggunakan teknik insidental. Instrumen yang digunakan adalah skala sikap konsumen sebanyak 57 item dengan skala keputusan membeli sebanyak 54 item. Hasil analisis menggunakan regresi linier sederhana menunjukkan $\mathrm{r}=0,865$ dan $\mathrm{p}=$ 0,000 dimana $\mathrm{p}<0,01$. Hal tersebut berarti bahwa ada hubungan yang sangat signifikan antara sikap konsumen dengan keputusan membeli produk perhiasan imitasi xuping. Sumbangan efektif yang diberikan oleh sikap konsumen terhadap keputusan membeli produk perhiasan imitasi xuping adalah sebesar 0,748 atau $7,48 \%{ }^{4}$

Kedua, penelitian Melisa Susanti pada tahun 2015 yang berjudul "Pasar Kaget terhadap Pemberdayaan Pedagang Kecil di Jatibarang-Indramayu". Dalam penelitian ini ditemukan bahwa dengan adanya pasar kaget dalam upaya pemberdayaan pedagang kecil memberikan dampak yang positif. Karena pasar kaget tersebut dapat dijadikan wadah ekonomi perdagangan. Menumbuhkan lapangan pekerjaan,

\footnotetext{
${ }^{4}$ Rina Oktaviana, "Hubungan Antara Sikap Konsumen Dengan Keputusan Membeli Produk Perhiasan Imitasi Xuping Pada Konsumen Wanita di Pasar 16 Ilir Palembang", Jurnal Ilmiah PSYCHE, Vol. 9, No. 2 (Desember, 2015): 140-146.
}

mengurangi angka pengangguran. Semua orang dapat menjajal atau memulai usaha dengan modal yang tidak harus besar, tidak perlu menyewa lapak atau kios untuk berdagang, lebih banyak pilihan dan harga yang terjangkau. Tentunya terlaksananya proses pemberdayaan pedagang kecil ini tidak terlepas dari peran, bantuan serta dorongan dari pihak pemerintah Indramayu dan pemerintah Desa Jatibarang. ${ }^{5}$

Dan kedua, penelitian Muhammad Irvan Alimudin dengan judul "Tinjauan Hukum Islam Terhadap Jual Beli Barang Hasil Bajakan". Hasil penelitian tersebut menunjukkan bahwa tinjauan hukum Islam terhadap jual beli barang hasil bajakan, yaitu 1) jual beli adalah merupakan suatu akad dan dipandang sah apabila telah memenuhi rukun dan syarat jual beli b) sebagaimana terkandung dalam UU No. 19 tahun 2002 tentang Hak Cipta dan juga fatwa MUI No. 1 tahun 2003 tentang Hak Cipta. Hak cipta adalah hak kekayaan intelektual yang dilindungi. Oleh karena itu sudah selayaknya berbagai pihak mendukung agar terciptanya masyarakat Indonesia yang bebas dari pembajakan, karena akan merugikan berbagai pihak yakni Negara pada umumnya dan khususnya pada masyarakat luas (c) jual beli barang hasil bajakan dalam hukum islam merupakan tindak pidana yang dalam istilah hukum Islam adalah jarimah. Perbuatan tersebut diancam dengan hukum ta'zir, dan jual beli barang hasil bajakan dilarang diperdagangkan karena dalil Al-Quran yang mengharamkannya. ${ }^{6}$

Dari ketiga penelitian terdahulu di atas belum terdapat yang mengangkat topik mengenai bagaimana penawaran produk imitasi dan proses pengambilan keputusan

\footnotetext{
${ }^{5}$ Melisa Susanti, "Pasar Kaget dan Pemberdayaan Pedagang Kecil di JatibarangIndramayu", Skripsi (Cirebon: Fakultas Syariah dan Ekonomi Islam IAIN Syekh Nurjati, 2015), ii.

${ }^{6}$ Muhammad Irvan Alimudin, "Tinjauan Hukum Islam Terhadap Jual Beli Barang Hasil Bajakan", Skripsi (Cirebon: Fakultas Syariah dan Ekonomi Islam IAIN Syekh Nurjati, 2015), i.
} 
konsumen di pasar kaget, sehingga bahasan ini menjadi topik yang menarik untuk penulis teliti.

\section{METODOLOGI PENELITIAN}

Dalam penelitian ini penulis menggunakan pendekatan metode kualitatif. Metode pendekatan kualitatif yaitu metode dalam meneliti status kelompok manusia, suatu objek, suatu sistem pemikiran dengan mengolah dan menginterpretasikan data berupa argumen serta data yang bersifat non angka. ${ }^{7}$ Penelitian ilmiah banyak bergantung pada cara peneliti menggumpulkan fakta. Karenanya metode dan rancangan penelitian menentukan valid atau tidaknya suatu penelitian yang dilakukan.

Jenis penelitian deskriptif kualitatif dengan cara mencari teori bukan mengkaji teori, menitik beratkan pada observasi dan suasana alamiah. Peneliti terjun secara langsung ke lapangan dan bertindak sebagai instrumen penelitian. ${ }^{8}$ Penelitian ini bermaksud untuk memahami fenomena tentang apa yang dialami oleh subyek penelitian misalnya perilaku, persepsi, motivasi, tindakan dan lain-lain; secara holistik dan dengan cara deskripsi dalam bentuk kata-kata dan bahasa, pada suatu konteks khusus yang alamiah dan dengan memanfaatkan berbagai metode alamiah. ${ }^{9}$

Tujuan dari metode deskriptif ialah untuk membuat deskripsi, gambaran atau lukisan secara sistematis, faktual dan akurat mengenai fakta-fakta, sifat-sifat serta hubungan antar fenomena yang diselidiki. Yaitu dengan menitikberatkan pada observasi dan suasana alamiah (naturalistis setting). Peneliti bertindak sebagai pengamat, membuat kategoresisasi perilaku, mengamati dan mendeskripsikan pengalaman individu.

\footnotetext{
${ }^{7}$ Made Wirartha, Metedologi Penelitian Sosial Ekonomi (Yogyakarta: C.V Andi, 2006), 134

${ }^{8}$ Elvinaro Ardianto, Metedologi Penelitian untuk Public Relations Kuantitatif dan Kualitatif (Bandung: Simbiosa Rekatama Media, 2011), 60.

${ }^{9}$ Lexy J. Moleong, Metodologi Penelitian Kualitatif (Bandung: Remaja Rosdakarya, 2004), 6.
}

Informan atau responden dalam penelitian ini adalah konsumen pasar kaget komplek Stadion Bima Cirebon yang mengkonsumsi produk-produk fashion yang ditawarkan disana. Hal ini didasari berdasarkan kenyataan bahwa pasar kaget komplek Stadion Bima Cirebon merupakan salah satu pusat peredaran produk-produk imitasi jenis fashion di Kota Cirebon. Peneliti mendapatkan limabelas informan yang terdiri dari enam orang sebagai pedagang dan sembilan orang merupakan konsumen produk fashion imitasi (delapan orang laki-laki dan tujuh orang perempuan). Peneliti memilih enam orang informan dari sisi pedagang karena mereka sudah berjualan ditempat tersebut lebih dari 2 tahun. Adapun sembilan orang yang dijadikan informan, rata-rata, mereka telah lebih dari 2 (dua) kali membeli produk fashion imitasi di area pasar kaget komplek Stadion Bima kota Cirebon. Hal ini merupakan satu indikator jika mereka adalah konsumen produk fashion imitasi. Selain itu, guna menunjang dan memperlengkap data, kami juga mewawancarai beberapa narasumber yang komprehensif di lokasi peneltian yang mengetahui seluk-beluk pasar kaget komplek Stadion Bima kota Cirebon sebagai data tambahan yang akan memperkuat dan melengkapi data-data yang diperlukan dalam penelitian ini.

Teknik pengumpulan data yang dipergunakan dalam penelitian ini adalah wawancara, observasi dan dokumentasi. Wawancara adalah teknik pengumpulan data dengan cara menanyakan secara langsung data yang dibutuhkan kepada seseorang yang berwenang. ${ }^{10}$ Penelitian ini melakukan wawancara mendalam (Indepth interview) terhadap beberapa informan penelitian yakni para pengunjung pasar kaget komplek stadion bima. Observasi yang dilakukan oleh peneliti yang bertindak sebagai orang luar atau pengamat dengan

${ }^{10}$ Burhan Bungin, Penelitian Kualitatif (Jakarta: Kencana, 2007), 126. 
tujuan untuk lebih memahami dan mendalami permasalahan. Dalam Observasi ini, peneliti melihat langsung situasi dan kondisi tempat penelitian. Observasi merupakan bentuk pengamatan tanpa mengajukan pertanyaan. $^{11}$ Dokumentasi adalah teknik pengumpulan data dengan melihat, membaca, mempelajari kemudian mencatat data yang ada hubungannya dengan obyek penelitian. Penggunaan metode dokumentasi ini ditujukan untuk melengkapi dan memperkuat data dari hasil wawancara, sehingga diharapkan dapat diperoleh data yang lengkap, menyeluruh dan memuaskan.

\section{KONSEP DASAR}

\section{Pengertian Pasar}

Menurut N. Gregory Mankiw dkk, pasar adalah sekelompok pembeli dan penjual dari sebuah produk atau jasa tertentu. Pembeli sebagai sebuah kelompok menentukan permintaan sebuah produk, sedangkan penjual sebagai kelompok lain yang menentukan penawaran dari produk tersebut. $^{12}$ Sedangkan menurut Ari Sudarman, pasar adalah suatu tempat di mana pembeli dan penjual bertemu untuk membeli atau menjual barang dan jasa atau faktor-faktor produksi. Di dalam bahasa sehari-hari pasar pada umumnya diartikan sebagai suatu lokasi dalam artian geografis. Tetapi dalam pengertian teori ekonomi mikro adalah lebih luas lagi. Suatu pasar dalam ilmu ekonomi adalah di mana saja terjadi transaksi antara penjual dan pembeli. $^{13}$ Dari pengertian di atas menjelaskan bahwa pasar adalah sebuah tempat bertemunya pembeli dengan penjual guna melakukan transaksi ekonomi yaitu untuk menjual atau membeli suatu barang dan jasa atau sumber daya ekonomi dan berbagai faktor produksi lainnya yang kini

\footnotetext{
${ }^{11}$ Made Wirartha, Metedologi Penelitian Sosial Ekonomi, 134.

${ }^{12}$ N. Gregory Mankiw, et.al., Pengantar Ekonomi Mikro (Jakarta: Salemba Empat, 2013), 62.

${ }^{13}$ Ari Sudarman, Teori Ekonomi Mikro (Yogyakarta: BPFE, 2004), 7.
}

tidak hanya menunjuk ke sebuah lokasi tertentu karena adanya sistem jaringan komunikasi yang modern.

Pasar mempunyai lima fungsi utama. Kelima fungsi utama ini menunjukkan pertanyaan-pertanyaan yang harus dijawab oleh setiap sistem ekonomi. Dalam sistem ekonomi persaingan sempurna, pasar menjawab semua pertanyaan-pertanyaan tersebut. Dalam sistem ekonomi komunistis, dilain pihak pertanyaan-pertanyaan tersebut dijawab oleh para perancang negara. Fungsi-fungsi tersebut adalah: $^{14}$ Pasar menetapkan nilai (set value), Pasar mengorganisir produksi, Pasar mendistribusikan barang, Pasar berfungsi menyelenggarakan penjatahan, Pasar mempertahankan dan mempersiapkan keperluan di masa yang akan datang.

Dipandang dari dari organisasi pasar atau strukturnya, bentuk pasar dibedakan menjadi dua macam, yaitu pertama, pasar persaingan sempurna. Pasar persaingan sempurna adalah struktur pasar yang dicirikan oleh jumlah pembeli dan penjual yang sangat banyak. ${ }^{15}$ Selain itu pasar persaingan sempurna bisa didefinisikan sebagai pasar yang dimana penjual dan pembeli tidak ada yang bisa mempengaruhi harga, sehingga harga yang terbentuk benarbenar hasil dari interaksi antara keduanya. Dan kedua, pasar persaingan tidak sempurna. Pasar persaingan tidak sempurna adalah pasar yang memiliki satu atau lebih penjual di pasar dan penjual dapat mempengaruhi harga yang terjadi di pasar. Pasar persaingan tidak sempurna, ${ }^{16}$ terdiri dari monopoli, oligopoly, dan monopoilistik.

\section{Penawaran Produk}

Produk adalah suatu sifat yang komplek baik yang dapat diraba maupun yang tidak

\footnotetext{
${ }^{14}$ Ari Sudarman, Teori Ekonomi Mikro, 8.

${ }^{15}$ Abdul Aziz, Ekonomi Islam Analisis Mikro dan Makro (Yogyakarta: Graha Ilmu, 2008), 111.

${ }^{16}$ Lia Amaliawati, Asfia Murni, Ekonomika Mikro (Bandung: PT. Refika Aditama, 2014), 238.
} 
dapat diraba, termasuk bungkus, warna, harga, pelayanan perusahaan dan pengecer, yang mana diterima oleh pembeli untuk memuaskan keinginan mereka. ${ }^{17}$ Menurut Kotler dan Amstrong dalam buku Nembah F. Hartimbul Ginting mendefinisikan: produk adalah segala sesuatu yang dapat ditawarkan ke pasar untuk perhatian, akuisisi, penggunaan dan konsumsi yang dapat memuaskan keinginan atau kebutuhan. $^{18}$

Produk merupakan segala sesuatu yang dapat ditawarkan produsen untuk diperhatikan, diminta, dicari, dibeli, digunakan, atau dikonsumsi pasar sebagai pemenuhan kebutuhan atau keinginan pasar yang bersangkutan. Jadi, produk mempunyai pengertian yang lebih luas dari sekedar barang yang dapat diukur. Dalam arti luas produk mencakup barang fisik, jasa, orang, organisasi, gagasan atau gabungan dari semua itu.

Penawaran (supply) adalah kata yang paling sering digunakan oleh para ekonom di samping pemintaan (demand). Keduanya adalah kekuatan yang mendorong bekerjanya ekonomi pasar dan yang menentukan berapa banyak sebuah barang dihasilkan dan berapa harga yang dikenakan untuk barang tersebut ketika dijual. ${ }^{19}$ Penawaran didefinisikan sebagai kuantitas barang yang ditawarkan di pasar pada berbagai tingkat harga. ${ }^{20}$ Dengan kata lain, penawaran dapat diartikan sebagai hubungan fungsional antara jumlah yang ditawarkan dengan tingkat harganya. Penawaran mencerminkan kesediaan produsen atau penjual untuk menawarkan

${ }^{17}$ Basu Swastha, Manajemen Pemasaran Analisa Perilaku Konsumen (Yogyakarta: BPFE, 1997), 165.

${ }^{18} \mathrm{Nembah}$ F. Hartimbul Ginting, Manajemen Pemasaran (Bandung: CV YRAMA Widya, 2011), 90.

${ }^{19}$ N. Gregory Mankiw, et.al., Pengantar Ekonomi Mikro, 61.

${ }^{20}$ Sudarsono, Buku Materi Pokok Pengantar Ekonomi Mikro (Jakarta: Karunika, 1986), 11. untuk dijual berbagai jumlah atau kuantitas suatu barang. ${ }^{21}$

Fungsi penawaran adalah fungsi yang memperlihatkan keterkaitan antara variable jumlah barang yang ditawarkan dengan variabel-variabel atau faktor-faktor yang mempengaruhinya. ${ }^{22}$ Hukum penawaran adalah suatu pernyataan yang menjelaskan tentang sifat hubungan antara harga sesuatu barang dan jumlah barang tersebut yang ditawarkan pejual. ${ }^{23}$ Dalam hukum ini dinyatakan bagaimana keinginan para penjual untuk menawarkan barangnya apabila harganya tinggi dan bagaimana pula keinginan untuk menawarkan barangnya tersebut apabila harganya rendah.

Faktor-faktor yang mempengaruhi penawaran, ${ }^{24}$ yaitu 1) Harga barang itu sendiri. Jika harga suatu barang naik, maka produsen cenderung akan menambah jumlah barang yang dihasilkan. 2) Harga barang lain yang terkait. Barang-barang substitusi dapat mempengaruhi penawaran suatu barang. Dapat dikatakan bahwa apabila harga substitusi naik, maka penawaran suatu barang akan bertambah, dan sebaliknya. 3) Harga faktor produksi. Kenaikan harga faktor produksi, seperti tingkat upah yang tinggi, bahan baku yang meningkat, atau kenaikan tingkat bunga modal, akan menyebabkan perusahaan memproduksi output-nya lebih sedikit dengan jumlah anggaran tetap. 4) Biaya produksi. Kenaikan harga input sebenarnya juga menyebabkan kenaikan biaya produksi. Dengan demikian, bila biaya produksi meningkat maka produsen akan mengurangi hasil produksinya, berarti penawaran barang itu

\footnotetext{
${ }^{21}$ Soeharsono Sagir, et.al., Kapita Selekta Ekonomi Indonesia (Jakarta: Kencana, 2009), 241. Mikro, 46.

${ }^{22}$ Lia Amaliawati, Asfia Murni, Ekonomika

${ }^{23}$ Sadono Sukirno, Mikroekonomi Teori Pengantar, Edisi Ketiga (Jakarta: PT RajaGrafindo Persada, 2016), 85.

${ }^{24}$ Pratama Rahardja dan Mandala Manurung, Teori Ekonomi Mikro: Suatu Pengantar (Jakarta: Lemabaga Penerbit Fakultas Ekonomi Universitas Indonesia, 2010), 28-30.
} 
berkurang. 5) Teknologi produksi. Kemajuan teknologi menyebabkan penurunan biaya produksi dan menciptakan barang-barang baru. 6) Jumlah pedagang atau penjual. Apabila jumlah penjual suatu produk tertentu semakin banyak, maka penawaran barang tersebut akan bertambah. 7) Tujuan perusahaan. Tujuan perusahaan adalah memaksimalkan laba, bukan memaksimumkan hasil produksinya. Akibatnya, tiap produsen tidak berusaha untuk memanfaatkan kapasitas produksinya secara maksimum, tetapi akan menggunakannya pada tingkat produksi yang memberikan keuntungan maksimum. 8) Kebijakan pemerintah. Kebijakan pemerintah juga dapat mempengaruhi penawaran suatu barang. Seperti halnya dalama kebijakan untuk impor beras dan meningkatkan produksi dalam negeri guna tercapainya swasembada beras.

\section{Pengambilan Keputusan Konsumen}

Sebelum membeli suatu produk atau jasa umumnya konsumen melakukan evaluasi untuk melakukan pemilihan produk atau jasa. Evaluasi dan pemilihan yang digunakan akan menghasilkan suatu keputusan. Proses keputusan konsumen bukanlah berakhir dengan pembelian, namun berlanjut hingga pembelian tersebut menjadi pengalaman bagi konsumen dalam menggunakan produk yang dibelinya tersebut. Pengalaman itu akan menjadi bahan pertimbangan untuk pengambilan keputusan pembelian di masa depan. ${ }^{25}$

Menurut Engel, bahwa proses pengambilan keputusan membeli mengacu pada tindakan konsisten dan bijaksana yang dilakukan untuk memenuhi kebutuhan. Sementara Setiadi menyatakan bahwa pengambilan keputusan konsumen adalah proses pengintegrasian yang mengkombinasikan pengetahuan untuk mengevaluasi dua atau lebih perilaku alternatif dan memilih salah satu

\footnotetext{
${ }^{25}$ Ma'ruf Hendri, Pemasaran Ritel (Jakarta:
} PT. Gramedia Pustaka Utama, 2006), 14. diantaranya. Berkowiz juga mengemukakan bahwa proses keputusan pembelian merupakan tahap-tahap yang dilalui pembeli dalam menentuka pilihan tentang produk dan jasa yang hendak dibeli. ${ }^{26}$ Berdasarkan uraian di atas, maka proses pengambilan keputusan sebagai seleksi terhadap dua pilihan alternatif atau lebih, dengan kata lain ketersediaan pilihan yang lebih dari satu merupakan keharusan dalam pengambilan keputusan yang dilakukan untuk memenuhi kebutuhan. Macam-macam proses pengambilan keputusan konsumen yaitu extended decision making, limited decision making, dan routine decision making. ${ }^{27}$

Menurut Kotler, untuk sampai kepada keputusan pembelian konsumen akan melewati lima tahap yaitu pengenalan masalah (problem recognition), pencarian informasi (information search), evaluasi alternatif (evaluation of alternatives), keputusan pembelian (purchase decision) dan perilaku pasca pembelian (postpurchase behavior). ${ }^{28}$ Menurut Kotler, tahap evaluasi alternatif dan keputusan pembelian terhadap minat membeli diawal yang mengukur kecenderungan pelanggan untuk melakukan suatu tindakan tertentu terhadap produk secara keseluruhan. ${ }^{29}$

Memahami perilaku konsumen dalam pengambilan keputusan bukanlah hal yang sederhana. Pelanggan mungkin menyatakan kebutuhan dan keinginan mereka namun dapat bertindak sebaliknya. Mereka mungkin menanggapi pengaruh yang merubah pikiran-pikiran mereka pada

\footnotetext{
${ }^{26}$ Anggi Putra Wijaya, “Tingkat Pemahaman Fiqih Muamalat Terhadap Keputusan Membeli Produk Fashion Palsu", Skripsi (Jakarta: Fakultas Syariah dan Hukum Islam UIN Syarif Hidayatullah, 2015), 22.

${ }^{27}$ Ujang Sumarwan, Perilaku Konsumen; Teori dan Penerapannya dalam Pemasaran, Edisi Kedua (Bogor: Ghalia Indonesia, 2011), 126.

${ }^{28}$ Philip Kotler, Manajemen Pemasaran: Analisis, Perencanaan, Implementasi, dan Pengendalian, 257.

${ }^{29}$ Philip Kotler, Manajemen Pemasaran, Jilid 1 (Jakarta: PT. Indeks Kelompok Gramedia, 2005), 223.
} 
menit-menit terakhir. Karenanya pemasar harus mempelajari keinginan, persepsi, preferensi serta perilaku belanja dan pembelian pelanggan sasaran mereka. Perilaku pembelian konsumen dipengaruhi oleh banyak faktor.

Kotler menyatakan bahwa perilaku pembelian konsumen dipengaruhi oleh berbagai faktor, seperti, faktor budaya, sosial, kepribadian dan kejiwaan. ${ }^{30}$ Keputusan pembelian dalam perpektif Islam. Islam adalah agama yang sempurna, yang mengatur seluruh perilaku manusia dalam segenap kehidupannya. Islam mengatur bagaimana manusia seharusnya melakukan kegiatan-kegiatan ekonominya. Berbagai kegiatan ekonomi berjalan dalam rangka mencapai satu tujuan, yakni menciptakan kesejahteraan keseluruhan, penuh ketegangan dan keseluruhan, namun tetap produktif dan inovatif bagi setiap individu muslim mapun nonmuslim. Allah telah menetapkan batas-batas tertentu terhadap perilaku manusia sehingga menguntungkan individu tanpa mengorbankan hak-hak individu lainya, sebagaimana ditetapkan oleh hukum Allah (syariah). ${ }^{31}$

Konsumen pada waktu akan membeli barang atau jasa didorong oleh berbagai motif antara lain motif rasional, motif selektif, dan motif emosional. Motifmotif yang mana mendorong seseorang untuk membeli banyak tergantung pada buying habit (kebiasaan membeli) mereka. Buying habit berarti kebiasaan membeli, biasanya ibu-ibu belanja pada tanggal muda, dan pada waktu rekreasi kadang-kadang nafsu belanjanya sulit ditahan, sehingga menimbulkan sifat boros, mengikuti ajakan setan. Hendaknya kita selalu bertindak rasional dalam berbelanja jangan terbawa

\footnotetext{
${ }^{30}$ Philip Kotler, Manajemen Pemasaran: Analisis, Perencanaan, Implementasi, dan Pengendalian, 231.

${ }^{31}$ M. Nur Rianto al-Arif dan Euis Amalia, Teori Mikroekonomi: Suatu Perbandingan Ekonomi Islam dan Ekonomi Konvensional (Jakarta: Kencana, 2010), 84.
}

emosional hingga melampaui batas. ${ }^{32}$ Hal tersebut dijelaskan dalam surat al-Isra' ayat 26-27, berikut ini:

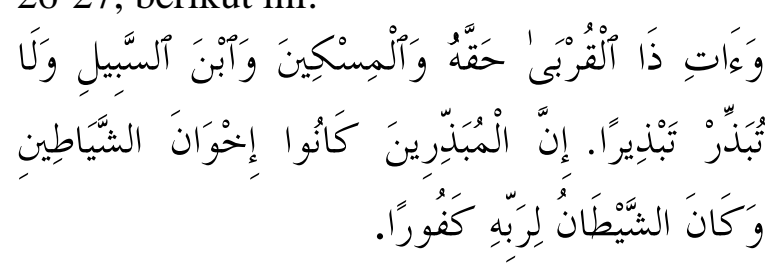

Artinya: Dan berikanlah kepada keluargakeluarga yang dekat akan haknya, kepada orang miskin dan orang yang dalam perjalanan dan janganlah kamu menghamburhamburkan (hartamu) secara boros. Sesungguhnya pemborospemboros itu adalah Saudarasaudara syaitan dan syaitan itu adalah sangat ingkar kepada Tuhannya. $^{33}$

Namun itu semua tidak berarti membuat kita menjadi kikir. Islam mengajarkan kepada kita sikap pertengahan dalam mengeluarkan harta, tidak berlebihan dan tidak pula kikir. Sikap berlebihan akan merusak jiwa, harta, dan masyarakat. Sememtara kikir adalah salah satu sikap hidup yang dapat menahan dan membekukan harta. ${ }^{34}$ Dalam surat al-Furqan ayat 67 Allah SWT. berfirman:

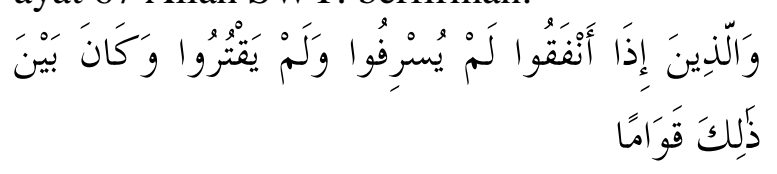

Artinya: Dan orang-orang yang apabila membelanjakan (harta), mereka tidak berlebihan, dan tidak (pula) kikir, dan adalah (pembelanjaan itu) di tengah-tengah antara yang demikian. $^{35}$

\footnotetext{
${ }^{32}$ Buchari Alma dan Doni Juni Priansa, Manajemen Bisnis Syariah (Bandung: Alfabeta, 2009), 122.

${ }^{33}$ QS. Al-Isra' (17): 26-27.

${ }^{34}$ Mustafa Edwin Nasution, et.al., Pengenalan Eksklusif: Ekonomi Islam (Jakarta: Kencana, 2007), 67.

${ }^{35}$ QS. Al-Furqan (25): 67.
} 
PEMBAHASAN DAN DISKUSI

\section{Konsep Bisnis Pasar Kaget Komplek Stadion Bima Kota Cirebon}

Pasar Kaget Komplek Stadion Bima berlokasi di Komplek olah raga Bima Kota Cirebon, J1. Bima Stadion, Kelurahan Sunyaragi, Kecamatan Kesambi, Kota Cirebon, Jawa Barat. Komplek Stadion ini pertama kali dibangun oleh Pertamina. , asal muasal Pasar Kaget Komplek Stadion Bima dapat dilihat sekitar enam tahun yang lalu. ${ }^{36}$

Hampir 80 persen pedagang pasar dadakan di Kompleks Bima menjual aneka pakaian selebihnya makanan, mainan dan kelontongan. $^{37}$ Bahkan, belakangan ini minimarket pun tak mau kalah. Tiap Minggu pagi banyak minimarket bahkan supermarket terkenal hingga dealer motor dan mobil turut membuka lapaknya di pasar kaget komplek Stadion Bima kota Cirebon. Tingginya jumlah masyarakat yang datang setiap minggunya menjadi magnet kuat bagi para pedagang untuk ikut serta membuka lapak di pasar kaget komplek Stadion Bima kota Cirebon.

Para pedagang dadakan ini biasanya membuka usaha dengan konsep food truck (menggunakan mobil sebagai etalase dagangannya). Di pasar kaget komplek Stadion Bima kota Cirebon dengan mudah dapat kita jumpai para pedagang yang menjadikan mobilnya sebagai etalase untuk tempat berjualan sepatu, baju dan perabotan rumah tangga. Akan tetapi, banyak juga pedagang yang lapak jualannya dengan cara membuka tenda dan sudah punya tempat khusus.

\section{Penawaran Produk Imitasi Jenis Fashion di Pasar Kaget Komplek Stadion Bima Cirebon}

Konsumen akan memberi reaksi pada stimuli atau rangsangan yang dirasakannya sehingga berminat untuk membeli produk

\footnotetext{
${ }^{36}$ Wawancara dengan ibu Rokmah, pedagang pada tanggal 29 Januari 2017.

${ }^{37}$ www.radarcirebon.com. Diakses pada tanggal 30 Januari 2017.
}

yang memiliki stimuli tertentu. Sumber rangsangan dari sebuah produk, baik itu asli maupun bajakan, adalah atribut-atribut pemasaran yang menurut banyak ahli disingkat dengan $4 \mathrm{P}$ yang terdiri atas: 1) Product (produk) 2) Price (harga) 3) Place (tempat) 4) Promotion (promosi). ${ }^{38}$

Apabila konsumen dapat merasakan keberadaan atribut-atribut pemasaran tersebut maka selanjutnya akan mengalami proses pemilihan, pengorganisasian dan pemberian arti sehingga sehingga menjadi suatu gambaran yang berarti dan berkaitan dalam benak konsumen. Pada proses ini juga terjadi pembandingan antara kenyataan atribut yang dirasakan dengan harapan atau kriteria evaluasi yang dimiliki oleh konsumen. Persepsi yang terbentuk terhadap suatu obyek tertentu tidak selalu sama antara satu konsumen dengan konsumen yang lain, hal ini disebabkan tiga proses persepsi yaitu perhatian selektif, distorsi selektif, dan ingatan selektif yang melibatkan kebutuhan, nilai dan harapan masing-masing individu konsumen. Sementara menurut Schiffman dan Kanuk persepsi seseorang turut dipengaruhi oleh kebutuhan, nilai-nilai dan harapannya. ${ }^{39}$

Pertama, Product (Produk). Produk imitasi jenis fashion yang beredar di Pasar kaget komplek Stadion Bima Cirebon berjumlah sangat banyak dan beragam. Dalam penelitian ini yang menjadi sorotan penulis adalah produk jenis fashion yang meniru dengan sempurna atau meniru bagian tertentu dari sebuah produk yang sudah ada sebelumnya. Produk fashion imitasi yang beredar di pasar kaget komplek Stadion Bima Kota Cirebon khususnya berupa jersey, kaos, jaket dan sepatu sebagian besar berasal dari kota di luar Cirebon (Jakarta, Bandung dan Surabaya). Terkecuali dengan produk fashion imitasi

\footnotetext{
${ }^{38}$ Buchari Alma, Manajemen Pemasaran dan Pemasaran Jasa, 205.

${ }^{39}$ Ujang Sumarwan, Perilaku Konsumen; Teori dan Penerapannya dalam Pemasaran, 360362.
} 
berupa kerudung dan pakaian muslim, sebagian besar berasal dari daerah Cirebon sendiri (Kota dan Kabupaten Cirebon). ${ }^{40}$ Produk imitasi jenis fashion yang ditawarkan disana selalu up to date atau menurut istilah sekarang dikenal dengan istilah "kekinian".

Kedua, Price (Harga). Harga merupakan salah satu faktor utama penentuan posisi dan harus diputuskan sesuai dengan pasar sasarannya, bauran ragam produk dan pelayanan, serta persaingan. Semua pengecer menginginkan margin yang tinggi dan mencapai volume penjualan yang besar, tapi biasanya kedua hal tersebut tidak dapat berjalan bersamaan. $^{41}$ harga untuk setiap produk fashion imitasi relatif terjangkau oleh masyarkat umum, kisaran antara sepuluh ribu hingga seratus lima puluh ribu, tergantung pada item produknya. Selain itu harga produk fashion imitasi yang ditawarkan memiliki selisih atau margin yang cukup besar jika dibandingkan dengan harga dari produk serupa yang original sehingga menarik minat konsumen untuk membelinya $^{42}$. Harga yang ditawarkan bukan herupakan harga pas dan bisa ditawar. Namun, mereka menemukan di beberapa tempat harga yang dipatok oleh pedagang sudah merupakan "harga pas" yang tidak dapat ditawar-tawar lagi, atau dengan kata lain tidak sebuah hal yang mutlak bahwa harga produk imitasi jenis fashion yang ditawarkan di Pasar Kaget bima seluruhnya mudah ditawar. Biasanya yang menerapkan harga pas (tidak dapat ditawar) adalah pedagang-pedagang yang telah memberikan harga diskon atau obral terhadap barang dagangannya. ${ }^{43}$

\footnotetext{
${ }^{40}$ Wawancara dengan bapak Jafar Shodiq, pedagang jersey imitasi pada tanggal 7 Mei 2017.

${ }^{41}$ Basu Swastha dan Irawan, Manajemen Pemasaran Modern (Yogyakarta: Liberty, 1990), 19.

${ }^{42}$ Wawancara dengan ibu Anis, pedagang jersey imitasi pada tanggal 30 April 2017.

${ }^{43}$ Wawancara dengan ibu Abdul Hafidz, pedagang jaket imitasi pada tanggal 7 Mei 2017.
}

Ketiga, Place (Tempat). Para pengecer biasa mengungkapkan tiga kunci keberhasilan adalah "lokasi, lokasi, lokasi". Hal ini menunjukkan bahwa keputusan lokasi merupakan keputusan sangat penting yang harus dibuat secara cermat. Pengecer memiliki pilihan untuk menempatkan usahanya di daerah pusat bisnis, pusat perbelanjaan regional, pusat perbelanjaan lingkungan, jalur perbelanjaan, atau pada suatu lokasi di dalam toko yang lebih besar atau dalam hal ini adalah bertempat di pasar kaget komplek Stadion Bima kota Cirebon. Pasar kaget komplek Stadion Bima kota Cirebon dapat dikatakan sebagai sebuah one stop shopping. Sebuah lokasi yang hampir mencakup sebagian besar kebutuhan para konsumen karena beragamnya produk dagangan yang dijajakan seperti, kuliner, fashion, otomotif hingga perabotan rumah tangga tersedia di sini. Selain itu, pasar kaget ini terdapat di dalam komplek Stadion Bima tempat masyarakat melakukan aktifitas olah raga, baik itu sekedar jogging atau aktifitas fisik lainnya yang dapat dilakukan di tempat ini. Jadi masyarakat yang datang ke sini, selain berolah raga juga bisa memenuhi kebutuhan-kebutuhannya yang tersedia di lapak-lapak pedagang yang bertebaran di sekitar area stadion. ${ }^{44}$

Keempat, Promotion (Promosi). Untuk merangsang atau menarik perhatian calon konsumen dan menciptakan pembelian serta memperkuat penentuan posisi citranya, para pedagang biasanya menggunakan berbagai macam alat promosi. Promosi dapat dikatakan salah satu agenda wajib pedagang untuk meningkatkan omset penjualan barang dagangannya. Bentuk promosi tersebut bermacam-macam, dapat berupa advertising, obral khusus, kupon potongan atau yang sedang menjadi trend pada saat ini menggunakan jalur media sosial, baik itu facebook, instagram, path, twitter dan lain sebagainya. Bentuk promosi yang banyak diterapkan oleh para pedagang

\footnotetext{
${ }^{44}$ Wawancara dengan ibu Dewi pedagang jaket imitasi, pada tanggal 7 Mei 2017.
} 
produk imitasi jenis fashion di pasar kaget komplek Stadion Bima adalah diskon, obral, ${ }^{45}$ dan bundling. ${ }^{46}$

\section{Pengambilan Keputusan Pembelian Konsumen Pasar Kaget Komplek Stadion Bima Cirebon}

Semakin bertambahnya pengetahuan seseorang akibat berkesinambungannya interaksi atau hubungan dengan aktivitas pembelian, kesadaran dan keinginannya untuk dapat melaksanakan segala sesuatu sesuai dengan kebutuhannya cenderung semakin besar. Tidak terkecuali dalam hal memilih produk fashion sebagai pilihan kebutuhan primernya. Dalam penelitian yang dilakukan penulis di pasar kaget komplek Stadion Bima kota Cirebon ditemukan bahwa sebagian besar responden, berdasarkan informasi yang mereka dapatkan, merasakan atribut-atribut pemasaran dari produk fashion imitasi yang mengarahkan mereka pada kebutuhan. Informasi awal yang mereka dapatkan mengenai kelebihan atribut produk fashion imitasi di pasar kaget bima kota Cirebon seperti dalam hal produk, harga, tempat penjualan maupun metode promosinya menyebabkan mereka mulai mengenali kebutuhan mereka dan mulai mempertimbangkan produk imitasi jenis fashion yang ditawarkan di Pasar Kaget bima Kota Cirebon.

Dalam wawancara yang dilakukan penulis diperoleh keterangan atau pernyataan yang memperlihatkan bahwa mayoritas responden mengakui bahwa mereka melakukan pencarian informasi tambahan yang berkaitan dengan atributatribut pemasaran produk fashion imitasi Pasar Kaget bima Kota Cirebon. ${ }^{47}$ Memang, dalam wawancara yang dilakukan penulis terhadap konsumen produk fashion

\footnotetext{
${ }^{45}$ Wawancara dengan ibu Anis, pedagang jersey imitasi pada tanggal 30 April 2017.

${ }^{46}$ Wawancara dengan ibu Iin, pedagang kerudung pada tanggal 30 April 2017.

${ }^{47}$ Wawancara dengan ibu Intan selaku konsumen pada tanggal 7 Mei 2017.
}

imitasi di pasar kaget komplek Stadion Bima kota Cirebon ditemukan responden yang mengaku tidak mencari informasi tambahan mengenai produk fashion imitasi, akan tetapi hal tersebut lebih dikarenakan pembelian ulang atau termasuk dalam kategori pengambilan keputusan yang terbatas bukan merupakan pembelian pertama. $^{48}$

Hal tersebut sebagaimana yang telah dijabarkan pada bab sebelumnya, bahwa pengambilan keputusan yang terbatas (Limited decision making) berlaku apabila konsumen menjalani semua tahap keputusan pembelian namun tidak menggunakan banyak waktu untuk setiap tahapnya. Kategori produk yang dibeli adalah produk yang sudah pernah dibeli sebelumnya namun tidak secara rutin, dengan resiko yang mungkin diterima moderat dan konsumen dapat berbelanja kapan saja. Tahap keputusan dilalui dibawah pengaruh pengalaman sebelumnya. Prioritas ditetapkan pada evaluasi alternatif yang sudah diketahui dengan mengacu kepada keinginan dan standar individu. ${ }^{49}$

Tahap evaluasi alternatif merupakan tahap dimana seorang konsumen akan membandingkan sejumlah produk, merek atau pasar lain berdasarkan informasi yang telah didapatkan sebelumnya untuk mendapatkan kriteria tertentu seperti yang diinginkan. Berdasarkan informasi yang diperoleh pada saat dilakukan wawancara terhadap responden, dapat dikatakan sebagian besar responden merasakan bahwa informasi yang mereka dapatkan mengenai produk fashion imitasi yang ditawarkan di pasar Kaget bima Kota Cirebon mendorong mereka untuk membandingkannya dengan beberapa alternatif produk fashion atau produk fashion imitasi lain yang sebelumnya pernah mereka kunjungi dan konsumsi baik itu dipertimbangkan dari sisi

\footnotetext{
${ }^{48}$ Wawancara dengan bapak Alam selaku konsumen, pada tanggal 7 Mei 2017.

${ }^{49}$ Buchari Alma, Manajemen Pemasaran dan Pemasaran Jasa, 106.
} 
keragaman produk, harga, maupun tempat penjualan produk. Masing-masing responden memilih alternatif produk dan tempat yang mungkin berbeda dengan responden yang lain. ${ }^{50}$

Pembelian merupakan merupakan tahap yang paling penting baik bagi konsumen maupun bagi pedagang. Pada saat menentukan pilihan tempat yang diambil sebagai tempat berbelanja atau membeli produk sesuai dengan kebutuhan, persepsi konsumen terhadap pelaksanaan atribut program pemasaran yang diketahuinya menjadi sangat penting. Sebagian besar responden menyatakan bahwa persepsi mereka terhadap pelaksanaan atribut program pemasaran produk fashion imitasi di pasar Kaget bima mengarahkan mereka kepada keputusan untuk memilih pasar kaget bima sebagai tempat berbelanja dan produk fashion imitasi sebagi pilihan konsumsi. ${ }^{51}$

Pengalaman yang diperoleh konsumen saat melakukan pembelian pada suatu tempat akan menimbulkan rasa puas atau tidak puas terhadap tempat maupun produk yang bersangkutan. Perlaksanaan atribut program pemasaran produk membentuk persepsi-persepsi dalam benak konsumen, jika persepsi yang terbentuk sesuai dengan pelaksanaan yang diharapkan oleh konsumen, maka konsumen akan merasa puas dan jika tidak, akan menimbulkan ketidakpuasan. Tanggapan responden mengenai produk imitasi jenis fashion di pasar kaget komplek Stadion Bima Cirebon bahwa mereka puas dengan kualitas produk fashion imitasi yang mereka beli sehingga mereka tidak ragu untuk melakukan pembelian ulang terhadap produk yang sama di tempat yang sama.

Hal ini menandakan bahwa responden sepakat bahwa produk imitasi jenis fashion yang diperdagangkan di pasar

\footnotetext{
${ }^{50}$ Wawancara dengan bapak Idham selaku konsumen pada tanggal 7 Mei 2017.

${ }^{51}$ Wawancara dengan bapak Ade selaku konsumen pada tanggal 30 April 2017.
}

kaget komplek Stadion Bima Cirebon memiliki kualitas produk yang baik. Artinya mereka menyetujui bahwa produk imitasi jenis fashion yang diperdagangkan di Pasar Kaget bima dapat memenuhi standar kualitas yang diharapkan konsumen. Dalam wawancara tidak ditemukan Responden yang menjawab tidak puas terhadap kualitas produk fashion imitasi yang diperjualbelikan di pasar kaget komplek stadion bima kota Cirebon. Artinya tidak ada responden yang tidak mengakui kualitas produk imitasi jenis fashion yang ditawarkan disana. Selain itu, hal ini menandakan bahwa mereka juga memiliki keyakinan tentang beragamnya dan lengkapnya jenis produk imitasi jenis fashion yang ditawarkan disana.

\section{KESIMPULAN}

Berdasarkan hasil penelitian, maka penulis dapat mengambil kesimpulan, sebagai berikut pertama, konsep bisnis yang terbentuk di pasar kaget komplek stadion bima kota Cirebon adalah retail atau eceran dengan tenda-tenda (tidak permanen) atau foodtruck sebagai tempat display barang atau produk dagangannya. Mereka (pedagang) berjajar di pinggi-pinggir jalan komplek Stadion Bima kota Cirebon.

Kedua, Produk imitasi jenis fashion yang beredar di pasar kaget komplek Stadion Bima kota Cirebon berjumlah sangat banyak dan beragam. Produk fashion imitasi yang dijajakan di pasar kaget komplek Stadion Bima kota Cirebon memiliki beberapa keunggulan sehingga menarik para pengecer untuk menjual produk tersebut. Dengan mengunggulkan harga yang lebih murah, kualitas barang yang memuaskan konsumen serta produknya memiliki kemiripan dengan produk originalnya sehingga hal tersebut dapat merangsang konsumen tertarik untuk melakukan pembelian produk tersebut. Hal ini tentu menjadi keuntungan bagi para pedagang serta kepuasan konsumen atas barang yang dibelinya. Bentuk promosi yang banyak diterapkan oleh para pedagang 
produk imitasi jenis fashion di pasar kaget komplek Stadion Bima adalah obral, diskon dan bundling.

Ketiga, pengambilan keputusan konsumen di pasar kaget komplek Stadion Bima kota Cirebon sebagian besar melalui lima tahap proses pengambilan keputusan pembelian konsumen yaitu, pengenalan kebutuhan, pencarian informasi, evaluasi alternatif, keputusan membeli dan perilaku pasca-pembelian. Namun terdapat beberapa konsumen dalam keputusan pembelian tidak melalui tahap-tahap tersebut dikarenakan konsumen tersebut melakukan pembelian spontan atau tidak memiliki banyak waktu untuk setiap tahap-tahapnya.

\section{DAFTAR PUSTAKA}

Al-Arif, M. Nur Rianto dan Euis Amalia. Teori Mikroekonomi: Suatu Perbandingan Ekonomi Islam dan Ekonomi Konvensional. Jakarta: Kencana, 2010.

Alimudin, Muhammad Irvan. "Tinjauan Hukum Islam Terhadap Jual Beli Barang Hasil Bajakan", Skripsi. Cirebon: Fakultas Syariah dan Ekonomi Islam IAIN Syekh Nurjati, 2015.

Alma, Buchari dan Doni Juni Priansa. Manajemen Bisnis Syariah. Bandung: Alfabeta, 2009.

Amaliawati, Lia dan Asfia Murni. Ekonomika Mikro. Bandung: PT. Refika Aditama, 2014.

Ardianto, Elvinaro. Metedologi Penelitian untuk Public Relations Kuantitatif dan Kualitatif. Bandung: Simbiosa Rekatama Media, 2011.

Aziz, Abdul. Ekonomi Islam Analisis Mikro dan Makro. Yogyakarta: Graha Ilmu, 2008.

Bungin, Burhan. Penelitian Kualitatif. Jakarta: Kencana, 2007.

Ginting, Nembah F. Hartimbul. Manajemen Pemasaran. Bandung: CV. YRAMA Widya, 2011.

Gobe, Marc. Emotional Branding: Paradigma Baru untuk
Menghubungkan Merek dengan Pelanggan. Jakarta: Esensi, 2005.

Hendri, Ma'ruf. Pemasaran Ritel. Jakarta: PT. Gramedia Pustaka Utama, 2006.

Kotler, Philip. Manajemen Pemasaran, Jilid 1. Jakarta: PT. Indeks Kelompok Gramedia, 2005.

Kotler, Philip. Manajemen Pemasaran: Analisis, Perencanaan, Implementasi, dan Pengendalian, Edisi Keenam. Jakarta: Erlangga, 1988.

Mankiw, N. Gregory. et.al., Pengantar Ekonomi Mikro. Jakarta: Salemba Empat, 2013.

Moleong, Lexy J. Metodologi Penelitian Kualitatif. Bandung: Remaja Rosdakarya, 2004.

Nasution, Mustafa Edwin, et.al. Pengenalan Eksklusif: Ekonomi Islam. Jakarta: Kencana, 2007.

Oktaviana, Rina. "Hubungan Antara Sikap Konsumen Dengan Keputusan Membeli Produk Perhiasan Imitasi Xuping Pada Konsumen Wanita di Pasar 16 Ilir Palembang", Jurnal Ilmiah PSYCHE, Vol. 9, No. 2 (Desember, 2015).

Rahardja, Pratama dan Mandala Manurung,

Teori Ekonomi Mikro: Suatu Pengantar. Jakarta: Lemabaga Penerbit Fakultas Ekonomi Universitas Indonesia, 2010.

Sagir, Soeharsono, et.al. Kapita Selekta Ekonomi Indonesia. Jakarta: Kencana, 2009.

Sudarman, Ari. Teori Ekonomi Mikro. Yogyakarta: BPFE, 2004.

Sudarsono. Buku Materi Pokok Pengantar Ekonomi Mikro. Jakarta: Karunika, 1986.

Sukino, Sadono. Mikroekonomi Teori Pengantar, Edisi Ketiga. Jakarta: PT RajaGrafindo Persada, 2016.

Sumarwan, Ujang. Perilaku Konsumen; Teori dan Penerapannya dalam Pemasaran, Edisi Kedua. Bogor: Ghalia Indonesia, 2011. 
Susanti, Melisa. "Pasar Kaget dan Pemberdayaan Pedagang Kecil di Jatibarang-Indramayu", Skripsi. Cirebon: Fakultas Syariah dan Ekonomi Islam IAIN Syekh Nurjati, 2015.

Swastha, Basu dan Irawan. Manajemen Pemasaran Modern. Yogyakarta: Liberty, 1990.

Swastha, Basu. Manajemen Pemasaran Analisa Perilaku Konsumen. Yogyakarta: BPFE, 1997.

Wijaya, Anggi Putra. "Tingkat Pemahaman Fiqih Muamalat terhadap Keputusan Membeli Produk Fashion Palsu", Skripsi. Jakarta: Fakultas Syariah dan Hukum Islam UIN Syarif Hidayatullah, 2015.

Wirartha, Made. Metedologi Penelitian Sosial Ekonomi. Yogyakarta: CV. Andi, 2006.

www.radarcirebon.com. 